\title{
PROTECTIVE ROLE OF EXOGENOUS NITRIC OXIDE AGAINST ZINC TOXICITY IN PLANTAGO MAJOR L.
}

\author{
NASIRI-SAVADKOOHI, S. ${ }^{1}-$ SAEIDI-SAR, S. $.^{1 *}-$ AbBASPOUR, H. ${ }^{1}-$ DeHPOUR, A. A. ${ }^{2}$ \\ ${ }^{I}$ Department of Biology, Islamic Azad University \\ Damghan Branch, Damghan, Iran \\ ${ }^{2}$ Department of Biology, Islamic Azad University \\ Qaemshahr Branch, Qaemshahr, Iran \\ *Corresponding author \\ e-mail:s_saeidisar@yahoo.com \\ (Received 24 $4^{\text {th }}$ Jan 2017; accepted $19^{\text {th }}$ May 2017)
}

\begin{abstract}
Zinc is one of the heavy metal in plants that causes toxicity at high concentration via producing Reactive oxygen species. Nitric oxide can protect cells from oxidative stress produced by reactive oxygen Species. Effect of different concentrations of $\mathrm{Zn}(0,100,300$ and $500 \mu \mathrm{M})$ and interaction with sodium nitroprusside (SNP, a donor of NO) $(100$ and $200 \mu \mathrm{M})$ were studied on growth parameter (total dry Weight) and some physiological factors (chlorophyll a, chlorophyll b, hydrogen peroxide and malondialdehyde contents), antioxidant enzymes (catalase, peroxidase, ascorbate peroxidase and Superoxide dismutase) in Plantago major L. Excess $\mathrm{Zn}$ reduced dry weight and chlorophyll content, resulting a decrease in photosynthesis. $\mathrm{Zn}$ stress induced the production of hydrogen peroxide $\left(\mathrm{H}_{2} \mathrm{O}_{2}\right)$, leading to malondialdehyde (MDA) accumulation. Furthermore, it was found that the activities of antioxidant enzymes in Zn-treated plants such as superoxide dismutase (SOD) and ascorbate peroxidase (APX) were decreased but peroxidase (POD) and catalase (CAT) were increased. The use of NO especially in low concentration reversed $\mathrm{Zn}$ induced negative effects whereas high concentration of $\mathrm{NO}$ had no obvious alleviating effect on $\mathrm{Zn}$ toxicity in Plantago major L. In particular, application of $100 \mu \mathrm{M}$ SNP could mitigate $\mathrm{Zn}$ stress, as a defense mechanism of the plant against $\mathrm{Zn}$ toxicity.
\end{abstract}

Keywords: heavy metal stress, sodium nitroprusside, antioxidative enzymes, ROS, hydrogen peroxide

\section{Introduction}

Zinc is an essential nutrient element for plants, as it is the component of many proteins like $\mathrm{Zn}$ finger-containing transcription factors, carbonic anhydrase, $\mathrm{Cu} / \mathrm{Zn}$ superoxide dismutase and $\mathrm{Zn}$ metalloproteases (Broadley et al., 2007). Many of these proteins have critical roles in the uptake and transport of $\mathrm{Zn}$, transcriptional regulation, RNA binding, regulation of apoptosis and protein-protein interactions (Ciftci-Yilmaz and Mittler, 2008). $\mathrm{Zn}$ toxicity can result in nutrient imbalance and induce the generation of excess reactive Oxygen species (ROS) (Wang et al., 2009). The excessive formation of ROS can oxidize various cellular components, resulting in lipid peroxidation, membrane leakage, and enzyme inactivation, which can finally lead to oxidative injury and alteration in the cell structure (Romero-Puertas et al., 2007).

Plants have many detoxification and tolerance mechanisms that mitigate and repair the ROS damages. One of these mechanisms includes antioxidant systems, which help them, survive in the altered environment. Antioxidant enzymes like superoxide dismutase (SOD), ascorbate peroxidase (APX), Catalase (CAT) and guaiacol peroxidase (POD), as well as 
antioxidant concentrations, like ascorbic acid, are activated by plants to alleviate oxidative stress (Tewari et al., 2008 ).

NO is an essential signaling molecule which modulates plant resistance to various abiotic stresses (Yu et al., 2014). NO is a highly reactive, membrane-permeable free radical that has recently emerged as a very important signaling molecule and antioxidant which triggers several types of redox-regulated (defense-related) gene expressions, directly or indirectly, to establish plant stress tolerance (Sung and Hong, 2010). The application of an NO donor, SNP, confers tolerance to various abiotic stresses in plants by enhancing their antioxidant defense system (Xu et al., 2010).

Several lines of study have shown that the protective effect of NO against abiotic stress is closely related to the NO-mediated reduction of ROS in plants (Hasanuzzaman et al., 2010). Exogenous application of SNP enhances plant tolerance to heavy metals (Oliviera et al., 2016) and oxidative stress (Esim and Atici, 2013). A recent report showed that NO was associated with long-term $\mathrm{Zn}$ tolerance in Solanum nigrum (Xu et al., 2010). NO involved on detoxification of $\mathrm{H}_{2} \mathrm{O}_{2}$ via modulation of antioxidant enzymes such as catalase (CAT),peroxidase (POD) and ascorbate peroxidase (AXP) and keeping of cell redox couple and non-protein antioxidant including thiol, ascorbate (Tewari et al., 2008). It also has been evidenced that NO stimulated the biosynthetic pathway of glutathione (GSH) in plant cells with an enhanced tolerance against oxidative stress (Xiong et al., 2010).

Plantago major is a medicinal herb with potent antioxidant effect .It belongs to the family of Plantaginaceae and is widely found in Europe and Asia in which Malaysia is one of the countries of its Habitat (Beara et al., 2009).

Nevertheless, the influence of exogenous NO on Zn stress tolerance in Plantago major plants is not yet fully understood. The present study was carried out to assess the impact of exogenous NO on reducing $\mathrm{Zn}$ toxicity in Plantago major L.

\section{Materials and Methods}

\section{Plant material and culture conditions}

Plantago major L. seeds were sterilized with 5\% sodium hypochlorite for $15 \mathrm{~min}$ and washed extensively with distilled water, then germinated on moist filter paper in the dark at $27^{\circ} \mathrm{C}$ for one week. Then, seedlings of uniform size were transferred to plastic pots filled with perlite ( 2 plants per pot) and irrigated by distilled water for 10 days. The seedlings were then nourished with half-strange Hoagland solution for three weeks, during 3 leaves stage irrigation was continued with half-strange Hoagland solutions containing different concentrations of $\mathrm{ZnSO} 4(0,100,300$ and $500 \mu \mathrm{M})$ and sodium nitroproside $(0,100$ and $200 \mu \mathrm{M}$ ) alone and together for two weeks. The experiment was carried out under a controlled environment, day/night temperature of $27 / 18^{\circ} \mathrm{C}$ and $65 \pm 5 \%$ relative humidity. For the estimation of plant dry matter content, the plants were dried at $80^{\circ} \mathrm{C}$ for $48 \mathrm{~h}$, to give a constant weight. 


\section{Determination of photosynthetic pigments}

The photosynthetic pigments (chlorophyll $\mathrm{a}$ and $\mathrm{b}$ ) was determined as per the method of Lichtenthaler (1987). Chlorophyll of experimental plant was extracted with $80 \%$ acetone and centrifuged. Supernatant was taken and optical density was measured at $663 \mathrm{~nm}$, $645 \mathrm{~nm}$. The chlorophyll $\mathrm{a}$ and $\mathrm{b}$ was calculated by Eq. 1 and 2 .

$$
\begin{aligned}
& \text { Chlorophyll a }(\mu \mathrm{g} / \mathrm{ml})=12.21 \times A 663-2.81 \times A 645 \\
& \text { Chlorophyll b }(\mu \mathrm{g} / \mathrm{ml})=20.13 \times A 645-5.03 \times A 663
\end{aligned}
$$

where $\mathrm{A}$ is the observed OD.

\section{Determination of lipid peroxidation}

Lipid peroxidation was determined by measuring MDA, a major thiobarbituric acid reactive species (TBARS), and product of lipid peroxidation (Heath and Packer 1968). Samples $(0.2 \mathrm{gr})$ are ground in $3 \mathrm{~mL}$ of trichloroacetic acid $(0.1 \%, \mathrm{w} / \mathrm{v})$. The homogenate was centrifuged at $10,000 \mathrm{~g}$ for $10 \mathrm{~min}$ and $1 \mathrm{~mL}$ of the supernatant fraction was mixed with $4 \mathrm{~mL}$ of $0.5 \%$ thiobarbituric acid (TBA) in $20 \%$ trichloroacetic acid (TCA). The mixture was heated at $95^{\circ} \mathrm{C}$ for $30 \mathrm{~min}$, chilled on ice, and then centrifuged at $10,000 \mathrm{~g}$ for $5 \mathrm{~min}$. The absorbance of the supernatant was measured at $532 \mathrm{~nm}$. The value for nonspecific absorption at $600 \mathrm{~nm}$ was subtracted. The amount of MDA was calculated using the extinction coefficient of $155 \mathrm{mM}^{-1} \mathrm{~cm}^{-1}$ and expressed as $\mathrm{nmol} \mathrm{g}{ }^{-1} \mathrm{FW}$.

\section{Estimation of hydrogen peroxide $\left(\mathrm{H}_{2} \mathrm{O}_{2}\right)$}

$\mathrm{H}_{2} \mathrm{O}_{2}$ concentration from leaf samples was measured according to the procedure of Velikova et al. (2000). Fresh leaf tissue (0.5 gr) was homogenized with $5 \mathrm{~mL}$ of $0.1 \%$ (w/v) (TCA) in a pre-chilled mortar and pestle and the homogenate was then centrifuged at $12,000 \mathrm{~g}$ for $15 \mathrm{~min}$. To $0.5 \mathrm{~mL}$ of the Supernatant, $0.5 \mathrm{~mL}$ of $10 \mathrm{mM}$ potassium phosphate buffer ( $\mathrm{pH} 7.0)$ and $1 \mathrm{~mL}$ of potassium iodide $(1 \mathrm{M})$ were added. The mixture was vortexed and its absorbance was read spectrophotometrically at $390 \mathrm{~nm}$.

\section{Determination of antioxidant enzymes}

For extraction of antioxidative enzymes, leaves and roots were homogenized with 50 $\mathrm{mM}$ Na2HPO4-NaH2PO4 buffer ( $\mathrm{pH} 7.8$ ) containing $0.2 \mathrm{mM}$ ethylene diamine tetra acetic acid (EDTA) and 2\% insoluble polyvinylpyrrolidone in a chilled pestle and mortar. The homogenate was centrifuged at 12,000 $\mathrm{g}$ for $20 \mathrm{~min}$ and the resulted supernatant was used for the determination of enzyme activities. The whole extraction procedure was carried out at $4^{\circ} \mathrm{C}$. SOD activity was assayed by measuring its ability to inhibit the photochemical reduction of nitroblue tetrazolium following the method of Stewart and Bewley (1980). CAT activity was measured as the decline in absorbance at $240 \mathrm{~nm}$ due to the decrease of extinction of $\mathrm{H}_{2} \mathrm{O}_{2}$ according to the method of Patra et al. (1978). POD activity was measured by the increase in absorbance at $470 \mathrm{~nm}$ due to guaiacol oxidation (Nickel and 
Cunningham, 1969). APX activity was measured by the decrease in absorbance at $290 \mathrm{~nm}$ as ascorbate was oxidized (Nakano and Asada, 1981).

\section{Statistical analysis}

All data presented here are the mean values of three independent experiments with three replicates. All results were analyzed statistically by two-way ANOVA with SAS 9.1.3 software and means were compared with the LSD test $(\mathrm{P}<0.05)$.

\section{Results}

\section{Biomass}

Effect of different concentrations of $\mathrm{Zn}(0,100,300$ and $500 \mu \mathrm{M})$ and interaction with sodium nitroprusside $(100$ and $200 \mu \mathrm{M})$ on plant growth, expressed as the total dry weight shown in Table 1. Zn exposure inhibited the growth of Plantago major significantly compared with control (Zn0Snp0), however, this inhibition was alleviated by the additions of $100 \mu \mathrm{M}$ SNP. When applying $200 \mu \mathrm{M}$ SNP into Zn-treated solution, Zn-induced inhibition on plant growth was not mitigated and the total dry weight reduced (Table 1).

\section{Photosynthetic pigments (chlorophyll $a$ and $b$ )}

A significant decrease in chlorophyll a and b contents was observed in the leaves of Plantago major, which were exposed to Zn stress. Compared with $\mathrm{Zn}$-stressed plants, the addition of $100 \mu \mathrm{M}$ SNP alleviated $\mathrm{Zn}$ toxicity in the photosynthetic apparatus. Whereas high concentration of SNP $(200 \mu \mathrm{M})$ had no alleviated effects on the Zn-decreased chlorophyll contents (Table 1).

\section{Hydrogen peroxide content}

$\mathrm{H}_{2} \mathrm{O}_{2}$ content in leaf and roots of Plantago major was increased depending on $\mathrm{Zn}$ concentrations. Under SNP concentrations, $\mathrm{H}_{2} \mathrm{O}_{2}$ content was decreased in low concentration and increased in high concentration of SNP. However, interactions between $\mathrm{Zn}$ and SNP concentrations showed that under $\mathrm{Zn}$ concentrations, the additions of SNP $100 \mu \mathrm{M}$ inhibited $\mathrm{Zn}$-induced $\mathrm{H}_{2} \mathrm{O}_{2}$ generation significantly (Table 1). This result indicates that the accumulation of $\mathrm{H}_{2} \mathrm{O}_{2}$ can reflect the oxidative stress and the changes of antioxidant in plants and indicates that low concentration of $\mathrm{NO}$ acts as an efficient ROS scavenger.

\section{Malondialdehyde content}

In the present study, the concentration of MDA was significantly increased $(\mathrm{P}<0.05)$ by $\mathrm{Zn}$ treatments in leaf and roots, which indicated an enhanced level of lipid peroxidation in metal-exposed plants. Under SNP concentrations, MDA content increases with increasing SNP concentrations. The application of SNP to $\mathrm{Zn}$ treatments shows that the low concentration of SNP $(100 \mu \mathrm{M})$ can alleviate the effects of Zn stress on lipid peroxidation (Table 1). 
Table 1. Effects of different concentrations of SNP on total dry weight, Chl $a$ and $b$, Leaf and Root MDA content, Leaf and Root $\mathrm{H}_{2} \mathrm{O}_{2}$ content in Plantago major under Zn stress

\begin{tabular}{|c|c|c|c|c|c|c|c|c|}
\hline $\mathbf{Z n}$ & SNP & $\begin{array}{c}\text { Total dry } \\
\text { weight } \\
\text { (gr) }\end{array}$ & $\begin{array}{c}\text { Chl a } \\
(\mathrm{mg} / \mathrm{g} \text { FW) }\end{array}$ & $\underset{(\mathrm{mg} / \mathrm{g} \text { FW) }}{\text { Chl b }}$ & $\begin{array}{c}\text { Leaf MDA } \\
\text { content } \\
\text { (nmol. } \\
\left.\mathbf{g}^{-1} \cdot \mathbf{F W}\right)\end{array}$ & $\begin{array}{c}\text { Root MDA } \\
\text { content } \\
\text { (nmol. } \\
\left.\mathbf{g}^{-1} \cdot \mathbf{F W}\right)\end{array}$ & $\begin{array}{c}\text { Leaf } \mathrm{H}_{2} \mathrm{O}_{2} \\
\text { content } \\
(\mu \mathrm{mol} . \\
\left.\mathrm{g}^{-1} . \mathrm{FW}\right)\end{array}$ & $\begin{array}{c}\text { Root } \mathrm{H}_{2} \mathrm{O}_{2} \\
\text { content } \\
(\mu \mathrm{mol} . \\
\left.\mathrm{g}^{-1} . \mathrm{FW}\right)\end{array}$ \\
\hline \multirow[t]{3}{*}{0} & 0 & & & $76067 \mathrm{a}$ & $26.5 \mathrm{j}$ & $17.563 \mathrm{j}$ & $22.737 \mathrm{i}$ & $17.46 \mathrm{~g}$ \\
\hline & 100 & & & & $27.417 \mathrm{i}$ & $17.993 \mathrm{j}$ & $23.073 \mathrm{i}$ & $17.267 \mathrm{~g}$ \\
\hline & 200 & & $2.567 \mathrm{bcd}$ & $0.727 \mathrm{~b}$ & $33.657 \mathrm{~g}$ & $21.444 \mathrm{i}$ & $24.93 \mathrm{~h}$ & $19.733 \mathrm{f}$ \\
\hline \multirow[t]{3}{*}{100} & 0 & & & $3 \mathrm{~b}$ & $.727 \mathrm{f}$ & $25.163 \mathrm{~h}$ & $26.956 \mathrm{~g}$ & $22.123 \mathrm{e}$ \\
\hline & 100 & & & & $.646 \mathrm{~h}$ & & & $903 \mathrm{e}$ \\
\hline & 200 & & & & & & & $63 d$ \\
\hline \multirow[t]{3}{*}{300} & 0 & & $2.02 \mathrm{f}$ & $0.6206 \mathrm{~d}$ & $3 \mathrm{e}$ & & & $66 \mathrm{~d}$ \\
\hline & 100 & & & & & & & $33 \mathrm{e}$ \\
\hline & 200 & $67 \mathrm{e}$ & $1.753 \mathrm{~g}$ & $0.5943 \mathrm{e}$ & $37.016 \mathrm{~d}$ & $34.373 \mathrm{c}$ & $29.703 \mathrm{~d}$ & $24.977 \mathrm{c}$ \\
\hline \multirow[t]{3}{*}{500} & 0 & & $1.45 \mathrm{~h}$ & $0.462 \mathrm{~g}$ & $40.203 b$ & $37.7533 b$ & $32.863 \mathrm{~b}$ & $25.583 \mathrm{~b}$ \\
\hline & 100 & & $2.02 \mathrm{f}$ & $0.5417 \mathrm{f}$ & $38.513 \mathrm{c}$ & $33.62 \mathrm{~d}$ & $26 c$ & $23.516 \mathrm{~d}$ \\
\hline & 200 & $0.43 \mathrm{~g}$ & $1.24 \mathrm{i}$ & $0.4126 \mathrm{~h}$ & $43.97 \mathrm{a}$ & $41.18 \mathrm{a}$ & $34.416 \mathrm{a}$ & $26.326 \mathrm{a}$ \\
\hline
\end{tabular}

Means followed by the same letter are not significantly different $(\mathrm{P}<0.05)$.

\section{Peroxidase enzyme activity}

According to Figs. 1 and 2, leaf and root POD enzyme activity increased significantly (at 0.05 level) under $\mathrm{Zn}$ stress condition. Under SNP concentration enzyme activity increased significantly (at 0.05 level) in $100 \mu \mathrm{M}$ and decreased significantly (at 0.05 level) in $200 \mu \mathrm{M}$. Interaction between $\mathrm{Zn}$ and SNP shows that enzyme activity increased significantly in $\mathrm{Zn}+\mathrm{SNP} 100 \mu \mathrm{M}$ and decreased significantly in $\mathrm{Zn}+\mathrm{SNP} 200 \mu \mathrm{M}$. It seems that NO in low concentration can improve negative effects of Zn stress (Figs. 1 and 2).

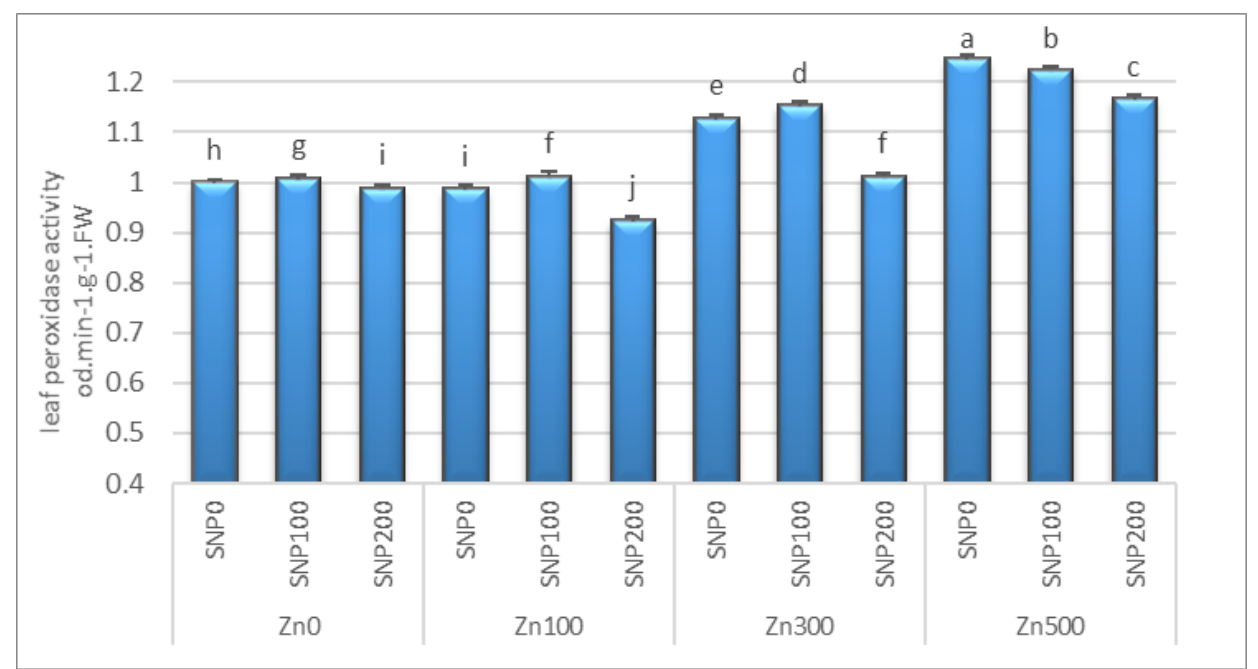

Figure 1. Effects of different concentrations of SNP on peroxidase activity in leaf of Plantago major under Zn stress $(P<0.05)$ 


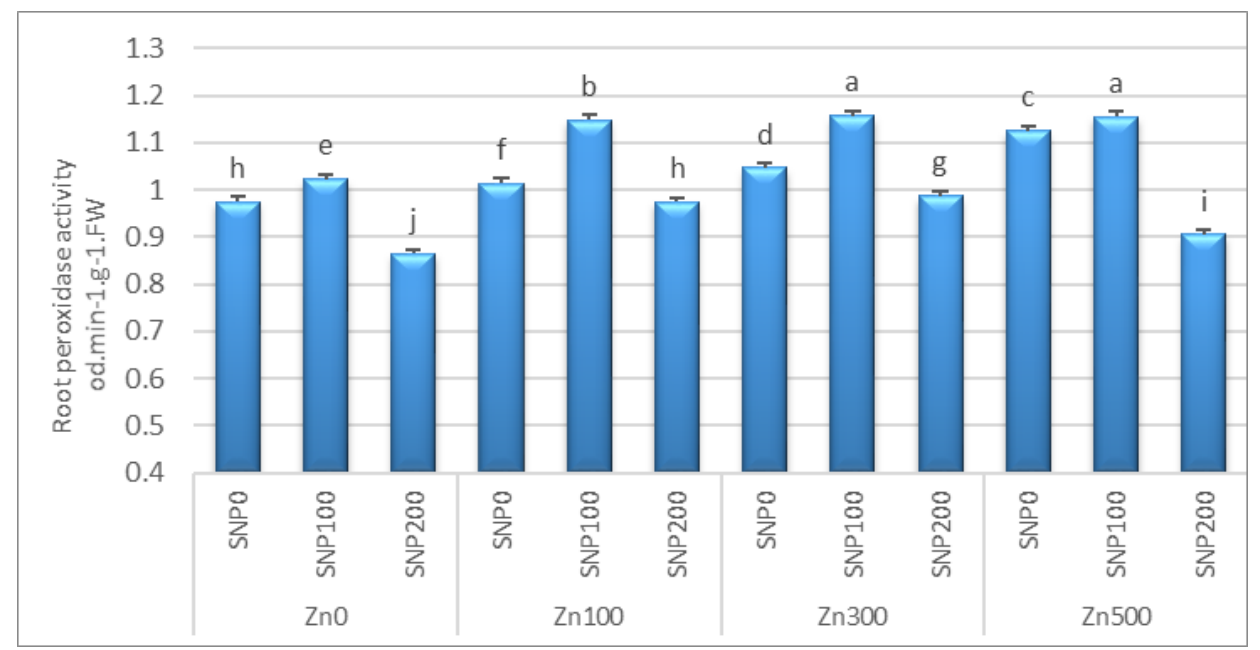

Figure 2. Effects of different concentrations of SNP on peroxidase activity in root of Plantago major under Zn stress $(P<0.05)$

\section{Catalase enzyme activity}

CAT enzyme activity increased significantly (at 0.05 level) under $\mathrm{Zn}$ stress condition compared with the control plant .Under SNP condition, there was decrease in SNP200 compared with SNP100. Generally, Zn treatment induced the activities of CAT in shoot and root of plantago major but this increase was found reversed in $200 \mu \mathrm{M}$ SNP treatment (Figs. 3 and 4).

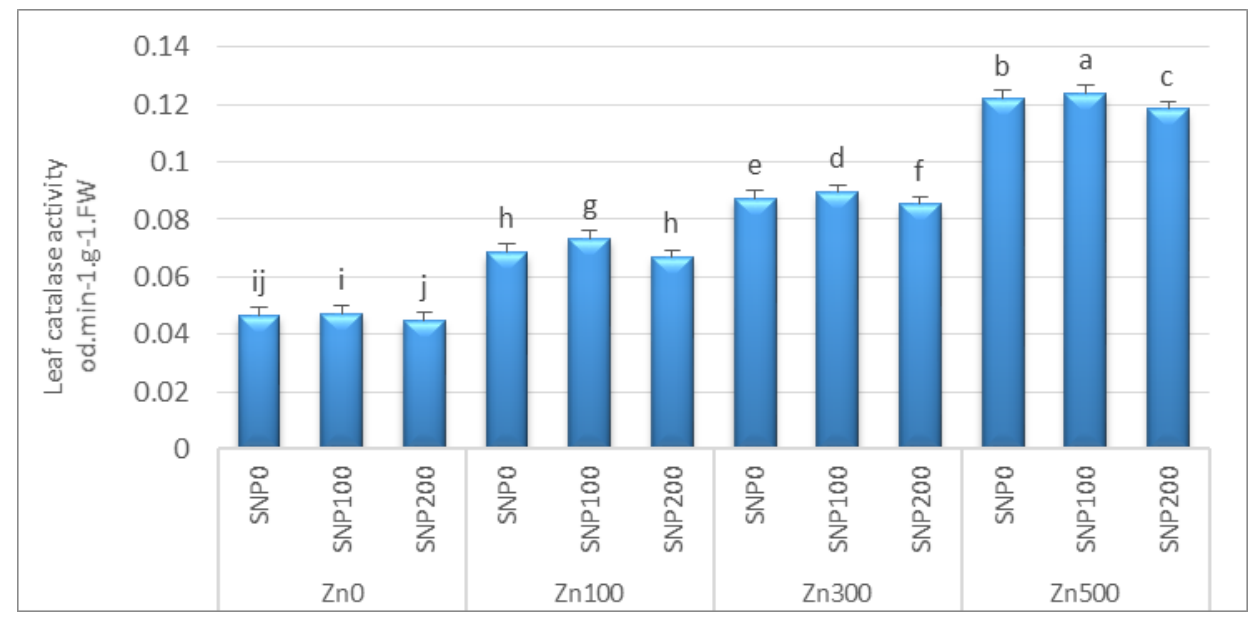

Figure 3. Effects of different concentrations of SNP on catalase activity in leaf of Plantago major under Zn stress $(P<0.05)$ 


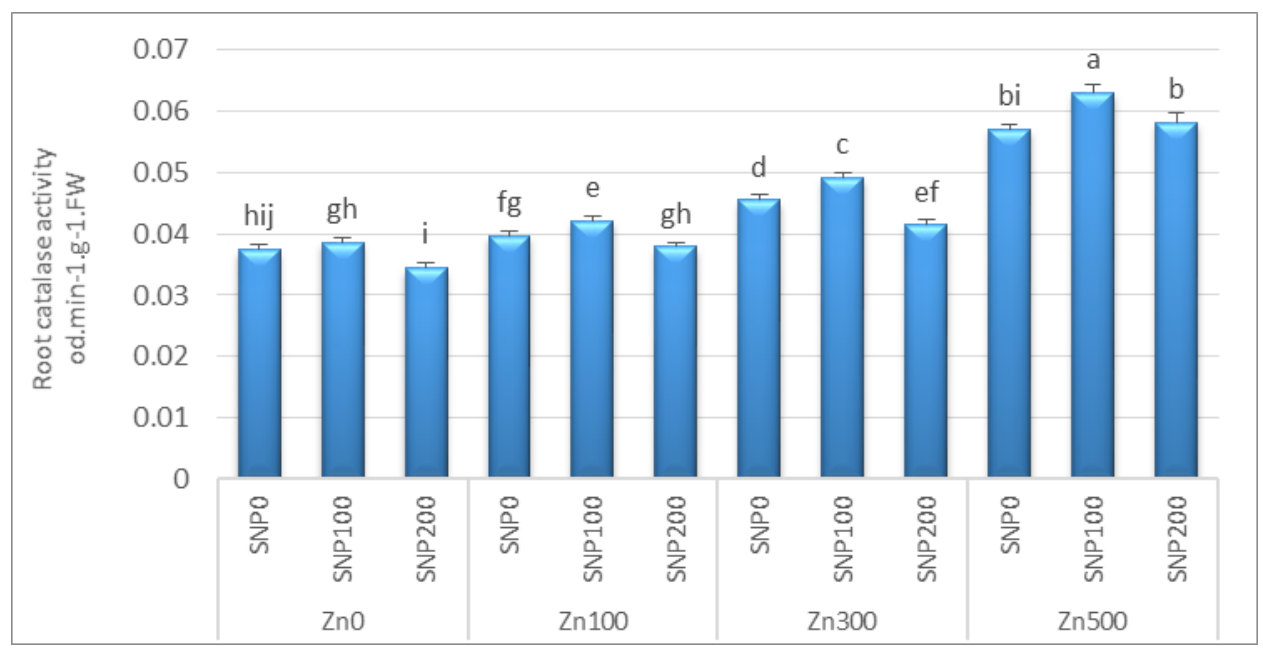

Figure 4. Effects of different concentrations of SNP on catalase activity in root of Plantago major under Zn stress

\section{Ascorbate peroxidase enzyme activity}

Leaf APX enzyme activity decreased significantly (at 0.05 level) with an increase of $\mathrm{Zn}$ concentrations. Under SNP concentration, the maximum activity of enzyme was found in $\mathrm{Zn}+\mathrm{SNP} 100$ and the minimum activity was identified in Zn+SNP200 (Fig. 5). Root APX enzyme activity under Zn stress increased significantly ( 0.05 level) from Zn0 to Zn100 and decreased significantly ( 0.05 level) with elevated concentrations of $\mathrm{Zn}$. In addition, under different concentrations of $\mathrm{Zn}$ treatments and SNP, showed that enzyme activity significantly decreased (0.05 level) in Zn+SNP200 and significantly increased (0.05 level) in $\mathrm{Zn}+\mathrm{SNP} 100$ (Fig. 6).

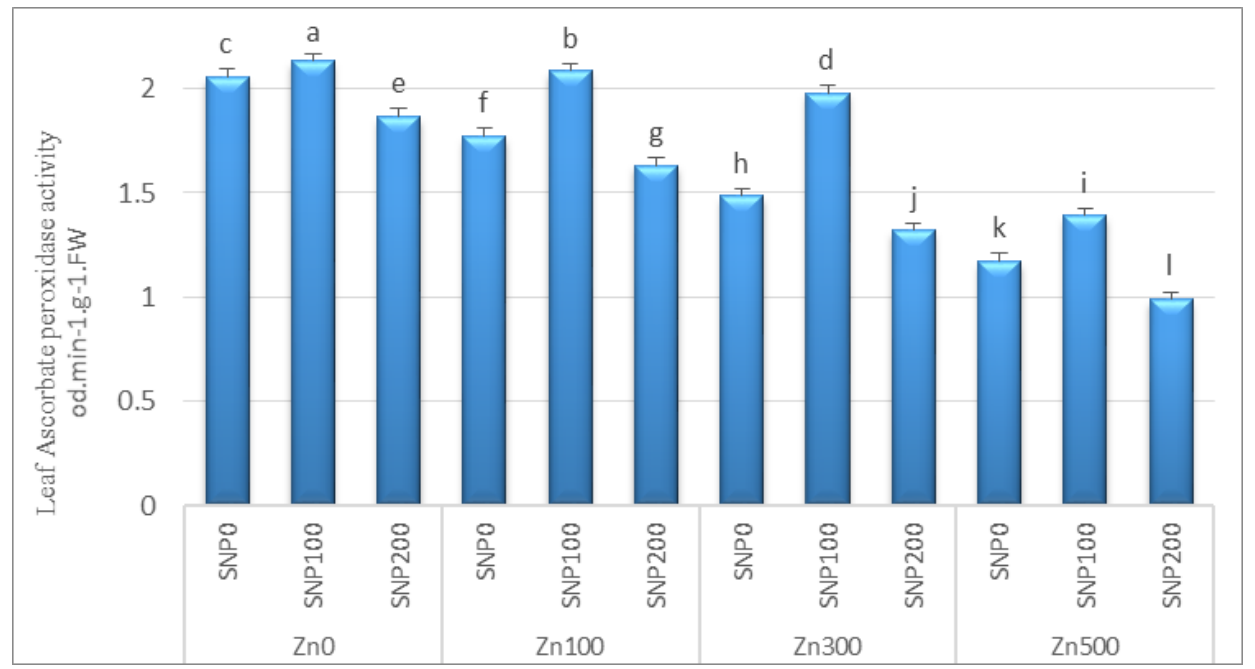

Figure 5. Effects of different concentrations of SNP on ascorbate peroxidase activity in leaf of Plantago major under Zn stress 


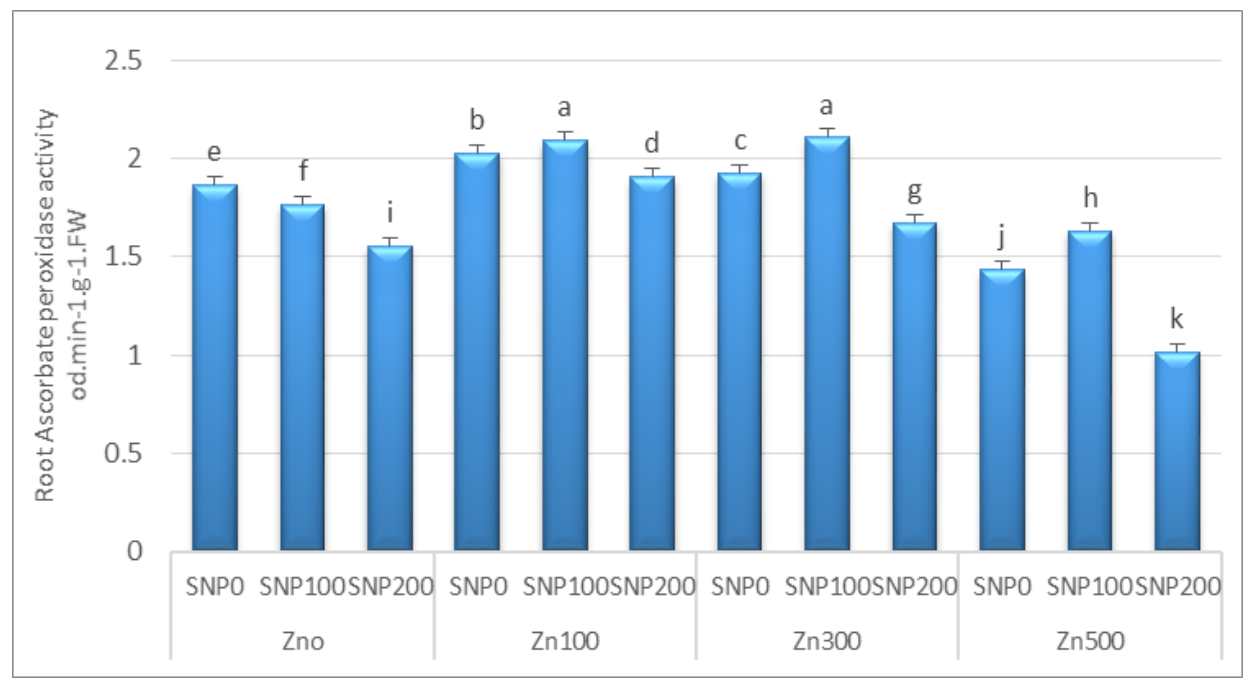

Figure 6. Effects of different concentrations of SNP on ascorbate peroxidase activity in root of Plantago major under Zn stress

\section{Superoxide dismutase enzyme activity}

In leaf and root of Plantago major, the highest level of SOD activity was seen at $100 \mu \mathrm{M}$ concentrations of $\mathrm{Zn}$. Under SNP concentration, enzyme activity decreased significantly (0.05 level) by increasing SNP. Application of SNP to $\mathrm{Zn}$ concentrations shows that the highest level of activity was seen at Zn $(0,100,300,500)+$ SNP100 and the lowest level of activity was seen at $\mathrm{Zn}(0,100,300,500)+$ SNP200. Hence, SOD activity was decreased depending on Zn concentrations, but the application of SNP200 $\mu \mathrm{M}$ caused a significant increase in SOD activity (Figs. 7 and 8).

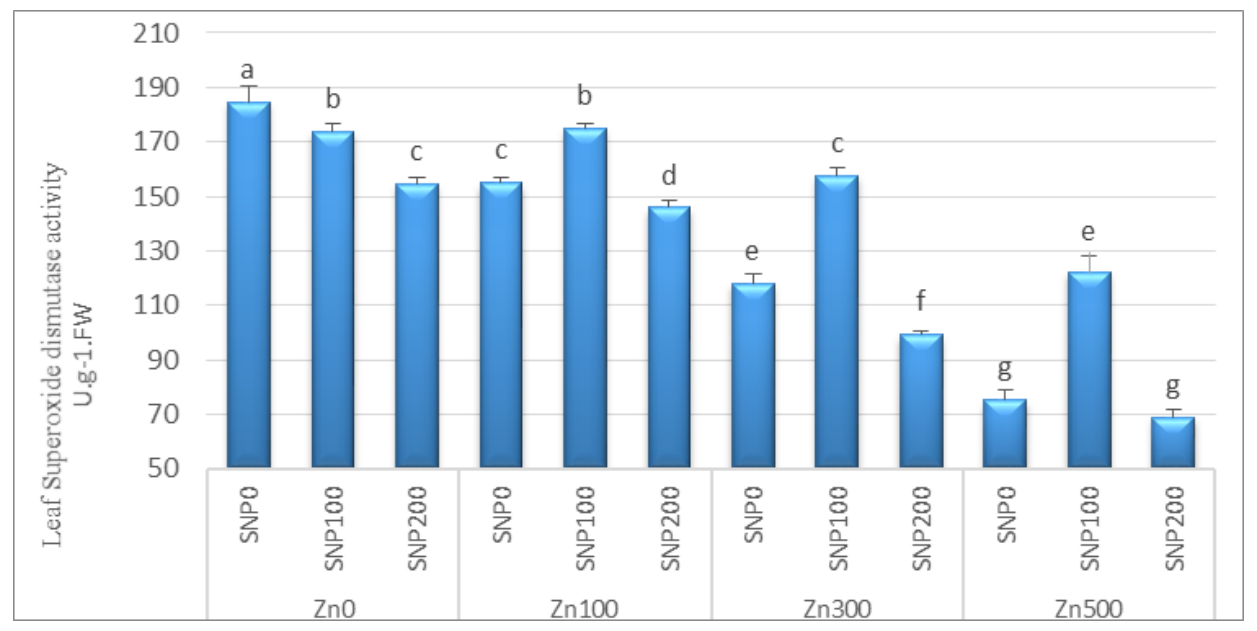

Figure 7. Effects of different concentrations of SNP on superoxide dismutase activity in leaf of Plantago major under Zn stress 


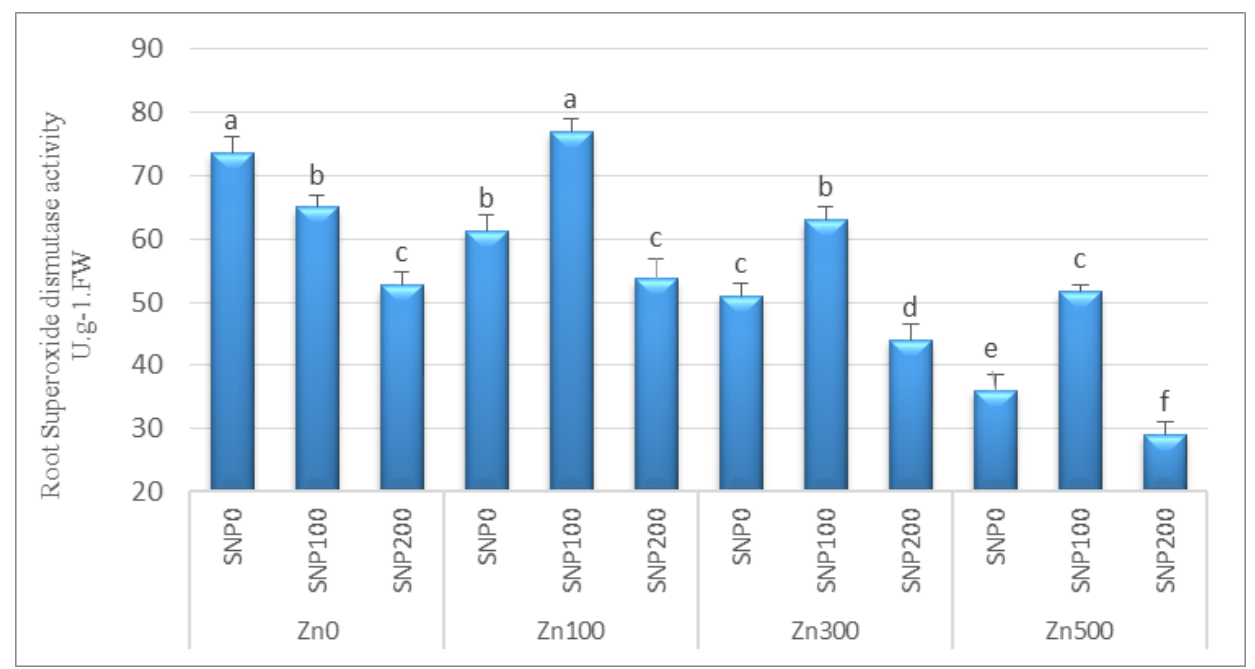

Figure 8. Effects of different concentrations of SNP on superoxide dismutase activity in root of Plantago major under Zn stress

\section{Discussion}

In our research, different NO concentrations were applied in Zn-treated growth medium. We investigated the physiological specifications of Plantago under $\mathrm{Zn}$ stress by using different NO concentration, aiming at finding a suitable concentration of NO to alleviate $\mathrm{Zn}$ toxicity effectively. The results of the present study indicated that application of $\mathrm{Zn} \mathrm{(100,}$ 300 and, $500 \mu \mathrm{M}$ ) especially concentration of $500 \mu \mathrm{M}$ decreased the dry weight of Plantago. However, simultaneous application of low concentration of NO $(100 \mu \mathrm{M})$ increased the dry weight. Zn-induced growth inhibition was reflected by total dry weight. Inhibition of growth in Plantago plants might be the result of $\mathrm{Zn}$ caused variation of metabolic processes, such as oxidative damage, nutrient uptake and photosynthesis. Sheldon and Menzies (2005) reported similar results on Rhodes grass. However, Zninduced inhibition was significantly reduced by the lower concentration of No. The mitigation effect of lower concentration of NO might be that NO induced the improvement of in photosynthesis by increasing chlorophyll content, counteracted oxidative damage by decreasing the generation of ROS. When the higher NO concentration was applied in Plantago plants, the mitigation effect was not obvious.

In this study, chlorophyll content showed maximum at $100 \mu \mathrm{M}$ of $\mathrm{Zn}$ and it was decreased beyond that concentration. The decrease in chlorophyll content is believed to be because of: (1) inhibition of enzymes associated with chlorophyll biosynthesis (John et al., 2009); (2) inhibition of uptake and transportation of other metal elements such as $\mathrm{Mn}$ and $\mathrm{Fe}$ by adversary effects (Jayakumar et al., 2009; John et al., 2009). These results are in agreement with Yuanjie et al. (2013) who reported that $\mathrm{Cu}$ significantly decrease total chlorophyll, chl. a and $b$ as compared with the control. The applications of different concentrations of SNP changed the chlorophyll contents in ryegrass. In another research, a similar reduction in total chlorophyll content under heavy metal toxicity was observed in Atriplex halimus (Brahim 
and Mohamed, 2011) and tobacco plants (Kheiry et al., 2016). Similar decrease in chlorophyll content under $\mathrm{Cu}$ stress was reported in Atriplex halimus. Our results shows that the application of exogenous $\mathrm{NO}$ at lower concentration $(100 \mu \mathrm{M})$ alleviated $\mathrm{Zn}$-induced decrease in chlorophyll content. Our results indicated that NO mediated improvement of chlorophyll contents played a role in the enhancement of photosynthesis.

As an active redox metal, $\mathrm{Zn}$ is able to induce the overproduction of ROS, such as hydrogen peroxide $\left(\mathrm{H}_{2} \mathrm{O}_{2}\right)$, which in turn lead to lipid peroxidation and oxidative stress (Zhang et al., 2009). Results of this study showed that high concentrations of $\mathrm{Zn}$, especially in $500 \mu \mathrm{M}$ induced over accumulation of $\mathrm{H}_{2} \mathrm{O}_{2}$ and MDA in leaves and roots, leading to the oxidative damage in Plantago plants. However, application low concentration of NO $(100 \mu \mathrm{M})$ alleviated $\mathrm{H}_{2} \mathrm{O}_{2}$ under $\mathrm{Zn}$ stress, protected cell membrane from peroxiding and decreased the accumulation of MDA. Similar to our results an increase in MDA and $\mathrm{H}_{2} \mathrm{O}_{2}$ content under excess nickel has been reported in Eleusine coracana L. (Viswanath et al., 2016).

The levels of lipid peroxidation in the plant cells are measured by the determination of their MDA content, a breakdown product of lipid peroxidation. A high level of MDA is expressive of an enhanced formation of ROS and oxidative damage. In fact, ROS delete hydrogen from unsaturated fatty acids and generates lipid radicals and reactive aldehydes, which distort the lipid bilayer (Mishra et al., 2006). The results in the present work are in adaptation with the explanation of Panda et al. (2003), who reported heavy metal induced oxidative stress in Wheat leaves cell. Zhang et al. (2014) investigated that excess Zn altered the redox status of the aquatic plants (Hydrilla verticillata). In support, Chao et al. (2008) reported rapid generation of $\mathrm{H}_{2} \mathrm{O}_{2}$ by $\mathrm{Zn}$-treated plant cells.

To cope with ROS and alleviate their toxic effects, plants have different antioxidation mechanisms (mediated by both enzymatic and non enzymatic antioxidants) operational in them to take care of the deleterious ROS (Puthur, 2016). Antioxidant system plays an important role in plant tolerance to stress conditions, which is based on the fact that the activity of one or more of these enzymes or antioxidant substances in general increase in plants when exposed to stressful condition and these enhances are related to increased stress tolerance (Fecht-Christoffers et al., 2003).

In our experiment, results shows that activities of antioxidant enzymes such as SOD and APX were decreased with increasing Zn concentrations but POD and CAT were increased. However, supply of exogenous NO, mainly $100 \mu \mathrm{M}$ improved the Zn-alteration on antioxidant enzyme activity, which played a role in alleviating $\mathrm{Zn}$-induced oxidative damage. Many studies have found a decrease (Malar et al., 2014) or increase (Xu et al., 2014) in activity of antioxidant enzymes under metal stress.

Previous reports revealed a variable response of an increase or decrease in SOD activity in plants exposed to different metals including Zn (Dixit et al., 2001). SOD is an essential component of antioxidant defense system in plants and it dismutase two superoxide radicals to water and molecular oxygen (Magdy and Azooz, 2013). A reduction in SOD activity in the metal treated plants has been attributed to an inactivation of the enzyme by $\mathrm{H}_{2} \mathrm{O}_{2}$ that is formed in different cellular compartments where SOD catalyzes the scavenging of superoxide radicals. SOD activity has been reported to increase under Zn toxicity (Kupper et al., 2007). Increase in SOD activity in response to stress appears to be probably due to de-novo synthesis of the enzymes protein (Erdei et al., 2002). Magdy and Azooz (2013) indicated that $\mathrm{Zn}$ treatment induced the activities of CAT and APX in shoots of Hibiscus 
esculentus. CAT is universally present oxidoreductase that decomposes $\mathrm{H}_{2} \mathrm{O}_{2}$ to water and molecular oxygen and it is one of the key enzymes involved in removal of toxic peroxides. CAT along with APX and SOD are considered as vital enzymes within the antioxidant defense mechanism, which directly determine the cellular concentration of $\mathrm{H}_{2} \mathrm{O}_{2}$ (El-Shora, 2004). All the antioxidant enzymes studied in this work explain maximum activity in leaf compared to roots. It might be due to translocation of $\mathrm{Zn}$ in aerial parts as a micronutrient and this augmented the concentration of antioxidant enzymes in leaf compared to roots. The increased antioxidant enzyme activity might be ascribed to the role of NO in stimulating the expression of their genes (Xiong et al., 2010; Shi et al., 2016). Two mechanisms, which may explain NO protective action against oxidative damage, have been reported. Firstly, NO might detoxify ROS directly, such as superoxide anion, to form peroxyntrite, which is less toxic and thus limit cellular damage (Martinez et al., 2000). Secondly, NO could function as a signaling molecule, which activates the cellular antioxidant system (Lamattina et al., 2003). In the present study, the application of high NO concentration did not reduce $\mathrm{Zn}$-induced ROS damage, even produced more toxic effects in Plantago major. However, the effects of NO depend on its concentration. Lamattina et al. (2003) reported that NO might regulate the expression of antioxidative genes to stimulate the relative enzyme activities. NO-mediated increase in one or more of these antioxidant enzymes contributed to the enhancement of antioxidative ability. Such results suggested that the protective effects of NO on oxidative damage were partly related to its role in upregulating antioxidative ability. Universally, $\mathrm{NO}$, as a recognized regulator of protein activation by S-nitrosylation, might inactivate heavy metal by modification of phytochelatins or some other ligands containing SH-group (Fecht-Christoffers et al., 2003). Finally NO can function as a signaling molecule for the cascade of events that lead to changes in gene expression under risk element stress (Procházková et al., 2012).

In conclusion, our results demonstrated that in the hydroponics experiment, the alleviation effects of NO on Zn stress in Plantago needed a suitable concentration and the lower concentration of NO $(100 \mu \mathrm{M})$ had a higher protective effect on $\mathrm{Zn}$ toxicity, while high concentration of NO $(200 \mu \mathrm{M})$ did not alleviate $\mathrm{Zn}$ toxicity effectively. Our study proved that exogenous $\mathrm{NO}$ at low concentrations increased $\mathrm{Zn}$ tolerance in Plantago grown in $\mathrm{Zn}$-mediated nutrient solution by (1) improving antioxidant enzyme activities and protecting against $\mathrm{Zn}$-induced oxidative stress, (2) reversed the $\mathrm{Zn}$ toxicity effect and decreased the MDA content and $\mathrm{H}_{2} \mathrm{O}_{2}$ accumulation. This indicates that $\mathrm{NO}$ acts as an efficient ROS scavenger and membrane stabilizer in Plantago plants exposed to Zn stress.

\section{REFERENCE}

[1] Beara, I. N., Lesjak, M. M., Jovin, E. D., Balog, K. J., Anackov, G. T., Orcic, D. Z. (2009): Plantain (Plantago L.) species as novel sources of flavonoid antioxidants. - Journal of Agricultural and Food Chemistry 57 (19): 9268-9273.

[2] Brahim, L., Mohamed, M. (2011): Effects of copper stress on antioxidative enzymes, chlorophyll and protein content in Atriplex halimus. - African Journal of Biotechnology 50: 10143-10148. 
[3] Broadley, M. R., White, P. J., Hammond, J. P., Zelko, I., Lux, A. (2007): Zinc in plants. New Phytologist 173: 677-702.

[4] Chao,Y. E., Zhang, M., Tain, S. K., Lu, L. L., Yang, X. E. (2008): Differential generation of hydrogen peroxide upon exposure to zinc and cadmium in the hyperaccumulating plant species (Sedum alfredii Hance). - Journal of Zhejiang University SCIENCE B 9: 243-249.

[5] Ciftci-Yilmaz, S., Mittler, R. (2008): The zinc finger network of plants. - Cellular and Molecular Life Sciences 65: 1150-1160.

[6] Dixit, V., Pandcy, V., Shyma, R. (2001): Differential antioxidative responses to cadmium in roots and leaves of pea (Pisum sativum L.). - Journal of Experimental Botany 52: 1101-1109.

[7] El-Shora, H. M., Abo-Kassem, E. M., Youssef, M. M. (2004): The toxic effects of cadmium and copper on the antioxidative enzymes and lipid peroxidation in marrow roots. - Mans. Science Bull 30: 127-140.

[8] Erdei, S., Hegedüs, A., Hauptmann, G., Szalai, J., Horváth, G. (2002): Heavy metal induced physiological Changes in the antioxidative response system. - Acta Biologica Szegediensis 46: 89-90.

[9] Esim, N. Atici, O. (2013): Nitric oxide alleviates boron toxicity by reducing oxidative damage and growth inhibition in maize seedlings (Zea mays L.). - Australian Journal of Crop Science 7 (8): 1085-1092.

[10] Fecht-Christoffers, M. M., Braun, H. P., Lemaitre-Guillier, C., Van Dorsselaer, A., Horst, W. J. (2003): Effect of manganese toxicity on the proteome of the leaf apoplast in cowpea. Plant Physiology 133: 1935-1946.

[11] Hasanuzzaman, M., Hossain, M.A., Fujita, M. (2010): Physiological and biochemical mechanisms of nitric oxide induced abiotic stress tolerance in plants. - American Journal of Plant Physiology 5: 295-324.

[12] Heath, R. L., Packer, L. (1968): Photoperoxidation in isolated chloroplasts: I. Kinetics and stoichiometry of fatty acid peroxidation. - Archives Biochemistry Biophysics. 125: 189-198.

[13] Jayakumar, K., Abdul Jaleel, C., Vijayarengan, P. (2009): Effect of different concentrations of cobalt on pigment contents of soybean. - Botany Research International 2 (3): 153-156.

[14] John, R., Ahmad, P., Gadgil, K., Sharma, S. (2009): Heavy metal toxicity: Effect on plant growth, biochemical parameters and metal accumulation by Brassica juncea L. International Journal of Plant Production 3: 65-76.

[15] Khairy, A. I. H., Oh, M. J., Lee, S. M. (2016): Nitric oxide overcomes Cd and Cu toxicity in in vitro-grown tobacco plants through increasing contents and activities of rubisco and rubisco activase. - Biochimie Open 2: 41-51.

[16] Kupper, H., Parameswaran, A., Leitenmaier, B., Trtilek, M., Setlik, I. (2007): Cadmiuminduced inhibition of photosynthesis and long-term acclimation to cadmium stress in the hyperaccumulator Thlaspi caerulescens. - New Phytologist 175: 655-674.

[17] Lamattina, L., Garcia-Mata, C., Graziano, M., Pagnussat, G. (2003): Nitric oxide: the versatility of an extensive signal molecule. - Annual Review Plant Biology 54: 109-136.

[18] Lichtenthaler, H. K. (1987): Chlorophyll and carotenoids: pigments of photosynthetic bio membranes. In: Douce, R., Packer, L. (eds) Methods Enzymol 148, 350-382. Academic press Inc, New York.

[19] Magdy, M. Y., Azooz, M. M. (2013): Biochemical studies on the effects of Zinc and Lead on oxdative stress, Antioxidant enzymes and Lipid peroxidation in Okra (Hibiscus esculentus cv.Hassawi). - Science International 1: 29-38.

[20] Malar, S., Vikram, S. S., Favas, P. J. C., Perumal, V. (2014): Lead heavy metal toxicity induced changes on growth and antioxidative enzymes level in water hyacinths [Eichhornia crassipes (Mart.)]. -Botanical studies 57:1-11. 
[21] Martinez, G. R., Mascio, P. D., Bonini, M. G., Augusto, O., Briviba, K., Sies, H. (2000): Peroxynitrite does not decompose to singlet oxygen ((1)Delta $(\mathrm{g}) \mathrm{O}(2))$ and nitroxyl $\left(\mathrm{NO}^{-}\right)$. Proceedings of the National Academy of Sciences 97: 10307-10312.

[22] Mishra, S., Srivastava, S., Tripathi, R., Kumar, R., Seth, C., Gupta, D. (2006): Lead detoxification by coontail (Ceratophyllum demersum L.) involves induction of phytochelatins and antioxidant system in response to its accumulation. - Chemosphere 65: 1027-1039.

[23] Nakano, Y., Asada, K. (1981): Hydrogen peroxide scanvenged by ascorbated specific peroxidase in spinach chloroplast. - Plant Cell Physiology 22: 867-880.

[24] Nickel, R. S., Cunningham, B. A. (1969): Improved peroxidase assay method using Ieuco 2, 3, 6-trichlcroindophenol and application to comparative measurements of peroxidase catalysis. - Analytical Biochemistry 27: 292-299

[25] Oliveira, H. C., Gomes, B. C. R., Pelegrino, M. T., Seabra, A. B. (2016): Nitric oxidereleasing chitosan nanoparticles alleviate the effects of salt stress in maize plants. - Nitric Oxide 61: 10-19.

[26] Panda, S. K., Chaudhary, I., Khan, M. H. (2003): Heavy metals induced lipid peroxidation and affect antioxidants in wheat leaves. - Biologia Plantarum 46: 289-294.

[27] Patra, H. L., Kar, M. Mishre, D. (1978): Catalase activity in leaves and cotyledons during plant development and senescence. - Biochemical Pharmacology 172: 385-390.

[28] Procházková, D., Haisel, D., Pavlikova, D., Schnablová, R., Száková, J., Vytášek, R., Wilhelmová, N.(2012): The effect of risk elements in soil to nitric oxide metabolism in tobacco plants. - Plant soil and environment 58: 435-440.

[29] Puthur, J. T. (2016):Antioxidant and cellular antioxidation mechanism in plants. - South Indian Journal of Biological Sciences 2: 14-17.

[30] Romero-Puertas, M. C., Laxa, M., Matte, A., Zaninotto, F., Finkemeier, I., Jones, A. M., Perazzolli, M., Vandelle, E., Dietz, K. J., Delledonne, M. (2007): S-Nitrosylation of peroxiredoxin II promotes peroxynitrite-mediated tyrosine nitration. - Plant Cell 19: 41204130.

[31] Sheldon, A. R., Menzies, N. W. (2005): The effect of copper toxicity on the growth and root morphology of Rhodes grass (Chloris gayana Knuth.) in resin buffered solution culture. Plant Soil 278: 341-349.

[32] Shi, J., Gao, L., Zuo, J., Wang, Q., Wang, Q., Fan, L.(2016): Exogenous sodium nitroprusside treatment of broccoli florets extends shelf life, enhances antioxidant enzyme activity, and inhibits chlorophyll-degradation. - Postharvest Biology and Technology116: 98104.

[33] Stewart, R. C., Bewley, J. D. (1980): Lipid peroxidation associated with accelerated aging of soybean axes. - Plant Physiology 65: 245-248.

[34] Sung, C. H., Hong, J. K. (2010): Sodium nitroprusside mediates seedling development and attenuation of oxidative stresses in Chinese cabbage. - Plant Biotechnology Reports 4: 243251.

[35] Tiwari, K. K., Deviwedi, S., Mishra, S., Srivastava, S., Tripathy, R. D., Singh, N. K., Chakraborty, S. (2008): Phytoremediation efficiency of Portulaca tuberosa Rox and Portulaca oleracea L. naturally growing in an industrial effluent irrigated area in Vadodra, Gujrat, India. - Environmental Monitoring and Assessment 147 (1-3): 15-22.

[36] Velikova, V., Yordanov, I., Adreva, A. (2000): Oxidative stress and some antioxidant systems in acid rain treated bean plants - Protective role of exogenous polyamines. - Plant Science 151: 59-66.

[37] Viswanath, K. K., Palaka, B. K., Ampasala, D. R.(2016): Alleviation of nickel toxicity in finger millet (Eleusine coracana L.) germinating seedlings by exogenous application of salicylic acid and nitric oxide. - The crop journal 16: 2214-5141. 
[38] Wang, C., Zhang, S. H., Wang, P. F., Qian, J., Hou, J., Zhang, W. J., Lu, J. (2009): Excess Zn alters the nutrient uptake and induces the antioxidative responses in submerged plant Hydrilla verticillata (L.f.) Royle. - Chemosphere 76: 938-945.

[39] Xiong, J., Fu, G., Tao, L., Zhu, C. (2010): Roles of nitric oxide in alleviating heavy metal toxicity in plants. - Archives Biochemistry Biophysics 497: 13-20.

[40] Xu, L. L., Dong, Y. J., Kong, J., Liu, S.(2014): Effects of root and foliar applications of exogenous NO on alleviating cadmium toxicity in lettuce seedlings. - Plant Growth Regulation 72: 39-50.

[41] Xu, Y., Sun, X., Jin, J., Zhou, H. (2010): Protective effect of nitric oxide on light-induced oxidative damage in leaves of tall fescue. - Journal of Plant Physiology 167: 512-518.

[42] Yu, M., Lamattina, L., Spoel, S. H., Loake, G. J. (2014): Nitric oxide function in plant biology: A redox cue in deconvolution. - New Phytologist 202: 1142-1156.

[43] Yuanjie, D., Linlin, X. U., Quanhui, W., Zhenyi, F., Jing, K., Xiaoying, B. (2013): Effects of exogenous nitric oxide on photosynthesis, antioxidative ability, and mineral element contents of perennial ryegrass under copper stress. - Journal of Plant Interactions. 9: 402-411.

[44] Zhang, S., Liu, K., Lv, X., Wang, P., Wang, C., Zhang, W., He, Z. (2014): Effects of nitric oxide on zinc tolerance of the submerged macrophyte Hydrilla verticillata. - Aquatic Biology 23: 61-69.

[45] Zhang, Y., Han, X., Chen, X., Jin, H., Cui, X. (2009): Exogenous nitric oxide on antioxidative system and ATPase activities from tomato seedlings under copper stress. Scientia Horticulturae 123: 217-223. 